\title{
A Model of School Improvement Specialist Coaches (SISC+) in Development Teaching Professionalism: A Conceptual Review
}

Gurumoorthy Poobalan, Zulhairul Ramlee, Roslee Talip, Sukuneswari Kaliappan

To Link this Article: http://dx.doi.org/10.6007/IJARBSS/v11-i6/10080

DOI:10.6007/IJARBSS/v11-i6/10080

Received: 06 April 2021, Revised: 10 May 2021, Accepted: 24 May 2021

Published Online: 05 June 2021

In-Text Citation: (Poobalan et al., 2021)

To Cite this Article: Poobalan, G., Ramlee, Z., Talip, R., \& Kaliappan, S. (2021). A Model of School Improvement Specialist Coaches (SISC+) in Development Teaching Professionalism: A Conceptual Review. International Journal of Academic Research in Business and Social Sciences, 11(6), 36-50.

Copyright: (c) 2021 The Author(s)

Published by Human Resource Management Academic Research Society (www.hrmars.com)

This article is published under the Creative Commons Attribution (CC BY 4.0) license. Anyone may reproduce, distribute, translate and create derivative works of this article (for both commercial and non-commercial purposes), subject to full attribution to the original publication and authors. The full terms of this license may be seen

at: http://creativecommons.org/licences/by/4.0/legalcode

Vol. 11, No. 6, 2021, Pg. 36 - 50

Full Terms \& Conditions of access and use can be found at http://hrmars.com/index.php/pages/detail/publication-ethics 


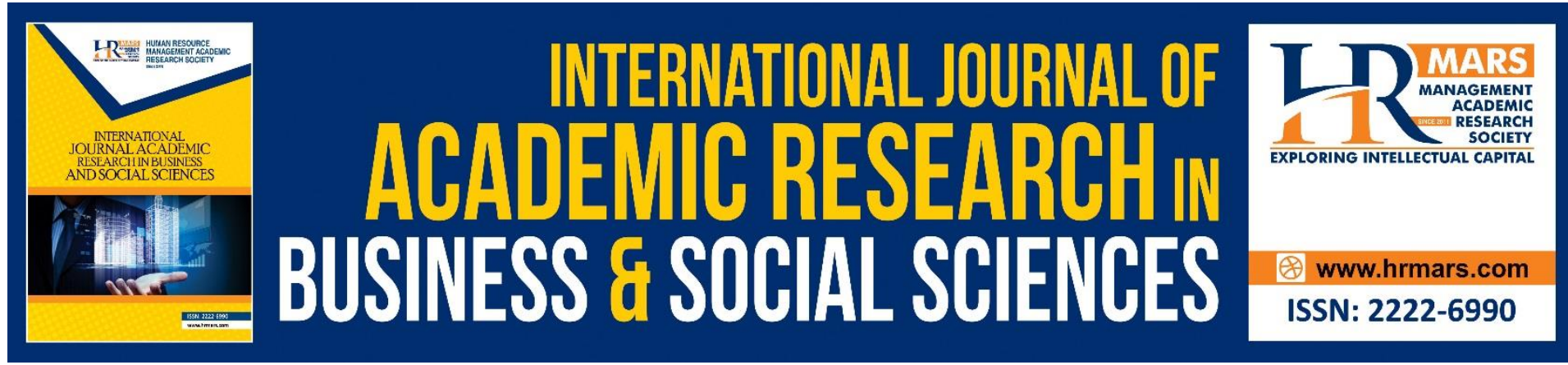

\title{
A Model of School Improvement Specialist Coaches (SISC+) in Development Teaching Professionalism: A Conceptual Review
}

\author{
Gurumoorthy Poobalan \\ Faculty of Psychology and Education, University Malaysia Sabah, 88400 Kota Kinabalu, \\ Sabah, Malaysia \\ Zulhairul Ramlee \\ SMK Beluran Peti Surat 30, 90107 Beluran, Sabah, Malaysia \\ Roslee Talip \\ Faculty of Psychology and Education, University Malaysia Sabah, 88400 Kota Kinabalu, \\ Sabah, Malaysia

\section{Sukuneswari Kaliappan} \\ SMK Balaban Jaya Peti Surat 108, 90108 Beluran, Sabah, Malaysia
}

\begin{abstract}
The Program for the Professional Schools Coaches Plus (SISC+) has been introduced in Malaysia since 2013 in order to boost teaching standards and achieve better student achievement in key subject areas, such as Bahasa Melayu and english and mathematics. Teacher training under the SISC + program in the Malaysian education system has various impacts. This research paper is to identify a model of SISC + coaching and mentoring initiatives in enhancing the growth of the teaching profession in line with the third wave of school transformation of the Malaysian Education Development Plan (2021-2025). Researchers discovered that the SISC + model is designed with five action steps based on the Growth Model to help teachers improve their teaching quality and develop teacher professionalism. To gain the necessary information, researchers have used library review. Based on the results, the researcher proposed a model that demonstrated teacher professionalism growth through SISC + in terms of knowledge and skills of pedagogical practices. The model is indirectly will help the middle leaders in school to focus on students achievement and teachers development. The study's results will fill in the gaps in future literature reviews of growth of teaching professionalism and the School Improvement Specialists Coaches Plus.
\end{abstract}

Keywords: Teaching Professionalism Development, Knowledge, Skill of Pedagogical Practices, School Improvement Specialists Coach Plus, Model 


\section{Introduction}

The SISC program, also known as School Improvement Specialist Coaches, was launched by the Malaysian Ministry of Education in early 2011 as part of the Government Transformation Programme (GTP) 1.0 sub-initiative of the National Key Research Area (NKRA). Selected teachers (the majority of whom are Outstanding Teachers) have received training as "master coachees" through courses.

After receiving this instruction, teachers would be assigned to track and direct teachers in low-performing schools, as well as those classified as Band 6 or Band 7. They must visit the supervised school at least three times a year to assess the school's issues and develop prevention / recovery plans that can be implemented in collaboration with the school's administrators and teachers. The curriculum was conducted in phases and on a part-time basis to assist the school in improving academic results. A very positive change was observed in terms of achievement on public examinations, especially the UPSR and SPM.

The presence of this role is also a result of the 6th Malaysian Education Development Plan 2013-2025, which states that it is intended to assist (State Education Department (JPN) and District Education Departments (PPD). The selected teachers will work full time in PPD but will not be actively involved in its management. SISC+ will oversee the school under its supervision four days a week, with an additional day dedicated to office work, report writing, and meeting. SISC + is currently only open for three core subjects: Bahasa Malaysia, English, and Mathematics. They are responsible for guiding teachers in pedagogy, PBS, and KSSR, as well as serving as a direct link between the Ministry and the school.

The full-time task of SISC+ is to perform guidance visits to schools to ensure that MOE policies and initiatives are being implemented effectively in order to raise the level of professionalism in teaching in terms of knowledge, skills, and values, as well as to organize and coordinate teacher training in their respective districts.

The rapid growth and change in education have obliged teachers to look for "up to date" information to better their education in the classroom. Moreover, the new breakthrough is to make students able to think about high level cognitive skills (HOTS). Teachers do also need guidance to meet the Ministry of Education's expectations.

In a study by Bibi et. al. (2019) the teacher guidance program under the supervision of the School Improvement Specialist Coach Plus (SISC+) was recommended to enhance teaching and learning at schools in Malaysia. Since SISC + full-time is the heart of their corpses and problems and we know even less of what we need for the benefit of the Theory, Strategy and Practice Programme. (Huong \& Abdullah, 2018; Jusoh, 2018 ; Ansawi \& Pang, 2017).

However, the perception of teachers based on past studies and the researchers' own experience indicate gaps between SISC + and teachers trained to improve student success and academic advancement in line with student expectations and growing professionalism. In addition, SISC+'s position in the spread of COVID-19 also reflected a gap in improving professional development and student education. This article will address the SISC+ model based on previous research in accordance with the standard of SISC+ that will lead to 
improvements in the growth of teacher development in line with the transformation of schools (2021-2025).

\section{Literature Review}

\section{A) Coaching And Mentoring}

Coaching and mentoring are beneficial factors in enhancing a person's ability to overcome issues when they arise. Coaching is a method of providing guidance to others in order to help them explain and accomplish their goals. This process has an effect on an individual's vision and beliefs while also providing consistent support (Huong \& Abdullah, 2018).

Under the SISC+ program, teachers may receive coaching and mentoring as part of their professional growth. This research used John Whitmore's GROW model, which was found to be appropriate for SISC+coaching activity. In a study conducted by Noel and Zamri. (2016), it was discovered that teachers would obtain a moderate level of guidance and mentoring, with a mean of 3.05 .

John Whitmore is the developer of the GROW Model. Since it is a more basic coaching foundation, this model is also used as a foundation for SISC+ in coaching and mentoring. According to previous research, mentor teachers tend to play a critical role in a teacher's professional growth. If the school and the SISC+ continue to support and encourage guided teachers, they will undoubtedly have a high level of confidence when teaching.

According to Asnia et.al. (2021), based on study of the relationship between coaching and guidance and metacognition among Malay language teachers indicate that the level of coaching and mentoring is high and thus suggest that teachers are ready to obtain coaching and mentoring feedback in order to enhance their teaching and learning abilities. Although not all coaching and mentoring things are significantly related to the metacognition of students, there is a substantial link between coaching or mentoring and teacher metacognition in terms of declaratory information.

According to Amirullah (2018), the efficacy of the learning in mathematical teachers outside the field or in 'no option' teachers, the Lesson approach to SISC + guidance builds conceptual understanding among students during the teaching and learning process. Research shows that after the student's response and achievement after the learning session, the performance of mathematics teachers increased. The teachers engage in the learning preparation, teaching and surveys, improving their skills and knowledge through discussions. Teachers are more confident in addressing student's issues and the 'classroom management approach' in the Lesson Study has helped to improve teacher skills and competence. SISC+'s participation in helping teachers to prepare learning and development through the activities of a Lessons Study will ultimately increase student performance and help skilled teachers grow.

In the report, Kadir et al. (2021) investigated the relationship between the role of coaching and mentoring among Malay teachers. The findings of research show that the degree of guidance and mentoring is high and thus show that teachers are prepared to obtain guidance from SISC+ in order to acquire metacognitive skills and to enhance their teaching and learning efficiency. 
According to Khun et.al (2019) in their report, interpersonal experience and skills dimensions in the SISC+ officers are influenced by improving the teaching skills of teachers. The findings of his research indicate that SISC + teachers have a relatively high level of instruction and teaching skills. This means that the SISC + mentoring service is available to teachers with changes. In addition, that study also shows that the relationship between SISC + teachers' guidance and teaching skills is positive but very poor. SISC+ officers therefore need to direct teachers in their role as professional educators to fulfill their needs and follow the guidelines for a more productive relationship. Moreover, statistics on regression showed that the SISC+ intelligence aspect affected just $6.3 \%$ of teachers' skills, while the interpersonal component was not important.

According to Balang (2020), in his research, SISC+ has the potential to recognise the ability to train teachers in schools and implement quality teaching and learning (T\&L). The results show that the level of SISC + curriculum knowledge is high. The results of this research show, from the perspective of the curriculum of the subjects taught, that SISC + is both responsible and professional. The research of his findings also include insights into SISC+ skills in teacher education and implementation of high-quality teaching and learning in schools (T\&L). Authorities must also provide assistance and collaboration to ensure that the SISC+ continues to be competent to provide teachers with quality guidance.

In the Balang et.al. (2020) study, the level of SISC + pedagogy competence was established. The results of this study show that SISC + is effective and familiar with the pedagogical aspects of the topic. The findings of his study provide a summary of SISC+'s strengths for school coaches and quality teaching and learning activities. Next, teachers connect and identify school and social issues. It is therefore acknowledged that the SISC + programming must be fully interpreted and recognized by schools and educational institutions in order to achieve their goal of teacher support. Physical space and the opportunity to work together will boost the success of a coach. The authorities must also provide assistance and cooperation in order to ensure that SISC+ is still capable of providing quality teacher guidance.

In Bibi et.al. (2019) research the teacher coaching program led by the School Improvement specialist coach Plus (SISC+) proposed a measure to enhance teaching and learning as an insitu continuous professional development (CPD) in schools. It has been more than 5 years (2014-2019) since SISC + has shouldered their bodies and problems in full time, and what we know is definitely much less necessary for the benefit of the theory, strategy and practice programme. (Ansawi \& Pang, 2017. Huong \& Abdullah, 2018.

In a research conducted by Elenchothy and Malathi (2019), a study on the impacts of teacher guidance programs (SISC+) on teacher skills and student success in the District Transformation Program (DTP). The findings of the study show that teachers' pedagogical skills have been strengthened in an attempt to evaluate and reflect.

According to Madhavan et.al. (2020), SISC+ coaching is in various dimensions which influence the quality of the instructor (teachers). 250 respondents from national primary school teachers participated in this quantitative analysis. This research uses the coaching instrument adapted from Sohee et al's management coaching instrument (2008). Coaching consists of five core aspects of effective communication, team approach, open principles, acceptance by 
teachers and the advancement of teachers. Overall, the factor of guidance in national primary schools drives the quality of teachers.

B) Model Grow

One of the most common coaching models, the GROW model, has been popular since it was introduced in the 1980s. It was founded in the 1980 s by Alan Fine, Graham Alexander and Sir John Whitmore (Whitmore, 1992). There are also different models and ideas regarding coaching's contribution to improving oneself. In principle, however, it is clear what should be done for successful professional development, few studies have been done on the effectiveness of growth (Theeboom et al. 2014). Mukherjee (2014) argues that the GROW model is a validated instrument of growth in performance used by most companies when addressing their employees' performance issues.

According to him, GROW's modeling principle has its roots in Timothy Galleway's internal game theory that was frustrated with the traditional weakness of sport coaching practices (Mukherjee, 2014). By means of the experience, learning is about learning how to learn and how to think differently. Sir John Whitmore was a student from Galleway and collaborated with Graham Alexander and Alan Fine in the early 1980s to create the GROW model (Western, 2012).

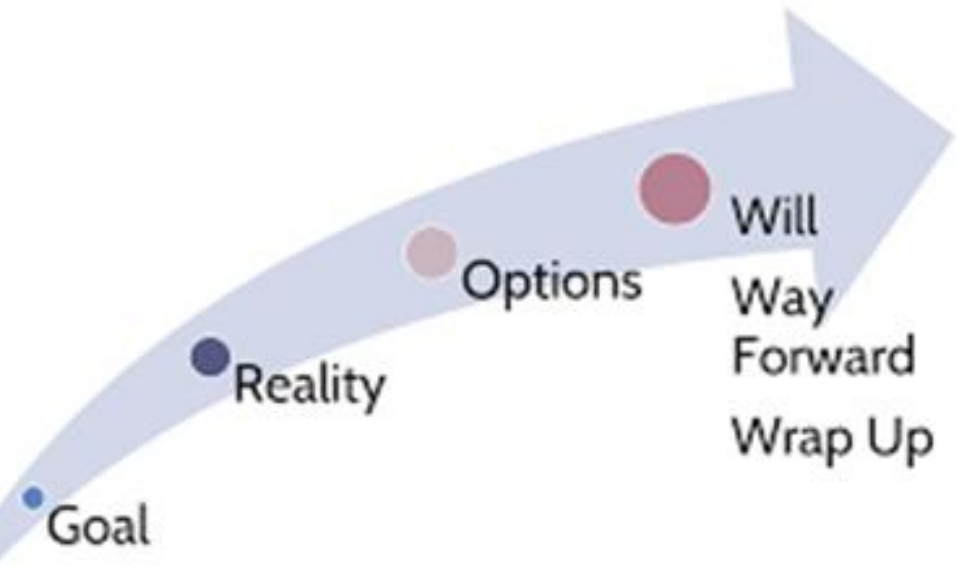

Figure 1. Grow Model ((Whitmore, J. (1992))

Whitmore (1992) defines development, the process of unlocking the ability of a person to optimize his or her own success, from the point of view of Galleway. The structure of the GROW building model is shown on the top in figure 1. According to Whitmore (2009), the GROW model is a solution-oriented model that helps in solving problems and achieving goals. The model consists of four stages that enable the coach to include the trainee. Each of the four different levels was suitable for setting goals, solving problems, maintaining personal success and competence (Leedham \& Parsloe, 2016).

First, coaches and trainees need to set objectives for development so they exist, the aim must be known so they can all achieve their objectives. Whitmore (2009) notes that setting priorities before looking at reality helps to establish objectives which are not affected by the current situation. At the same time, the purpose should be SMART: precise, observable, appropriate, timely and practical (Bianco-Mathis et al. 2002) Therefore, clear and precise 
targets must be set. Starr (2016) argues that the concept of setting goals is extremely relevant to the theory of setting goals, which is straightforward, precise and demanding as this contributes to clear guidance and motivations.

The second level is a reality in which trainees explain existing realities and aspects that actually allow them to see the reasons for improvement. (Weinstein, 2009). It is necessary for both parties to know how the issue is resolved when they do not have a clear picture of the intended destination. According to Bridges \& Bridges (2017), those who do not grasp the target without thinking of the point of departure are not able to resolve problems. As a mentor, a vital task is to promote self-assessment of the trainee and to recognise obstacles to it.

In the third step, the option is to generate ideas that can help solve problems. It includes exploring a number of options and focussing not only on the right approach, but also on some other options for a specific move (Dembkowski \& Eldridge, 2003). It is important to figure out the solution and then test each choice by creatively brainstorming the process. A coach should ensure that the trainee feels comfortable in an atmosphere to share his thoughts and ideas without fear of being judged.

The final step of the GROW construction model is the precise selection of a wide selection of types. Later, the choice was changed to a more concrete plan. Once the strategy is well designed, the coach's motivation to see this plan is maximized. The final phase of the solution of discussion into decision by taking specific actions to move forward (Lesley et al. 2015) As a coach, one of the most important is to guide the trainee or teacher to improve their performance by helping them make better decisions, solving problems that hinder them. Trainees also have new knowledge and do things in different ways, and in turn, they are able to advance their careers.

This GROW model is not only applied by SISC + officers but also closely related to school administrators in guiding their teachers to achieve learning and facilitation according to the set objectives.

C) Teaching Professionalism Development

In career planning, every teacher should focus on the creation of teacher professionalism. Teachers are facing more and more problems now and in the future. The issues faced are not only student problems and equipment, but also challenges for teachers' wisdom in confronting a knowledge-based society and identity in addressing more global issues of importance. Different educational topics have often questioned the teaching profession.

Based on the literature review conducted from different research sources, may the problems relating to these teachers' professionalism must be highlighted. So, We must therefore prioritize growth Professionalism among teacher and SISC+ will be source in contribute to improving teaching professionalism. The lack of qualifications or skills for teachers of various formal backgrounds (Kamaruddin and Boon, 2020) is perceivable; the lack of skills as well as a need to overcome the gap in teaching professionalism can be implemented through learning from the coaching and mentoring through SISC+. 
Teachers should have and inspire a variety of skills when it comes to integrating 21st centurybased learning and facilitation. The sharing of teacher skills and competences in classroom management (Irmawati et.al., 2021) is very significant, in accordance with the guidance of SISC + which can build partnerships and debate to improve student engagement through quality teachers. In this scenario, Internet technology also helps to increase the standard of the development of teachers (Kao et.al., 2020).

Teaching in today's schools is extremely difficult, and teachers must constantly plan and improve their professional skills in order to keep up with changing curriculum and tasks. In Malaysia, the Ministry of Education has introduced 'SKPMg2' (Standard 4) as one of the instruments to be implemented in schools for all teachers as a reference in their preparation and teaching in implementing learning and facilitation (KPM, 2016). Teachers were led by school coaches (SISC + ) by using the form to demonstrate an increase in teaching quality and teaching and learning is more successful as well as improving student achievement ( Norhasma \& Yusoff, 2019).

Sharing classroom issues with other teachers enables teachers to establish learning goals, create teaching aids, organize interactive teaching learning events, and promote active student learning and critical thinking skills. This is one way to enhance the standard of teaching and the professionalism of teachers by incorporating 21st-century educational attributes (Rachmajanti et.al, 2020). Collaboratively learning these shared lessons has been shown to benefit both teachers and students (Godfrey et al., 2019).

Additionally, the level of professionalism of teaching staff in schools does not always meet government standards, as the results of school self-assessment serve as a guide for school principals when developing the school's vision, mission, and objectives, as well as the principal's policy for developing teaching staff professionalism (Muntholibet.al , 2020).

Furthermore, teachers' participation in the conferences in which they are conducted has the value of instilling a sense of professionalism, as well as providing a positive sense of community and assisting in the development of their professional identity (Rimmer \& Floyd, 2020).

Improving the standard, capability, pedagogical-professional competence, and promoting the teaching profession should all be part of the ongoing effort to improve teacher competencies. A learning group can be built by collaborative teachers who use a continuous framework and a cycle centered on cooperative learning. One of the collaborative principles that can promote the growth of teacher professionalism is the use of SISC+ coaching.

The basic principle of Lesson Study implementation consists of three activities: (1) prepare, (2) do, and (3) observe (plan). (2) Execution (doing something) or observation and learning. (3) Student and teacher improvement may be aided by reflection on the preparation and execution of learning through Lesson Study activities (Purwasih et.al, 2020).

According to Al-Bakri, \&Troudi (2020), there is a perception among teachers that their participation in professional development activities, especially in terms of enhancing contextspecific skills activities, is lacking in institutional support. As a result, educational institution 
support is crucial, and it must be prioritized in order to enhance teachers' ability to perform on a global scale.

During the management and transmission of COVID-19 infection around the world, the creation of concepts based on information transmission and an efficient virtual learning environment will help teachers and students enhance the quality of their teaching and learning while maintaining teacher professionalism (Chan et.al, 2020 and Roche, 2021).

Close and dedicated partnership between public and private universities, teacher education agencies, and schools is a significant strategy for enhancing the growth of research-based teacher professionalism in schools and strengthening the standard of practice in teacher education. The University of Oslo, for example, has ten years of experience dealing with university-school relationships, in which both types of institutions have specific and complementary ways of complementing and improving teacher professionalism in teacher education (Hatlevik et.al., 2021).

According to the findings report.'s of Hatlevik et al (2021), collaboration between universities and schools can influence the standard of teaching, evaluation, and training forms on campus and in school practice. between teacher intuition and school education, as well as indirectly promoting teacher professionalism development.

\section{Methodology}

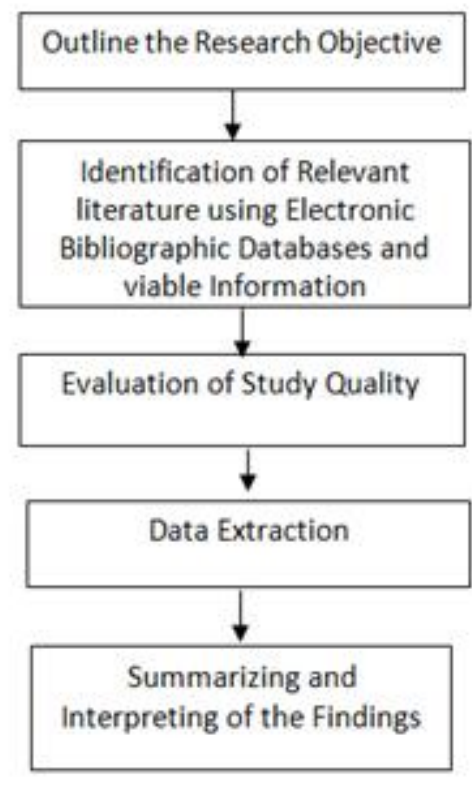

Figures 2.0 Represents of the systematic approach of the literature

Integrate socially responsible and expert support for teacher growth like that provided by SISC will aid in their overall professional development. Systematic study of diverse studies to collect the facts was used to gain information about the overall effectiveness of a system Therefore, the aim of this conceptual study is to formulate coherent elements of SISC+ practitioners and tutors to help teachers evolve in terms of their understanding, competencies, principles, and practices. 
This study explores various studies to illustrate how the SISC capabilities can help teachers in enhancing their professionalism while also enabling better educational technology standards through SISC interventions. The methods used in Figure 2.0 demonstrate our approach. Systematic and advanced search engines are employed to evaluate SISC+ training that uses both book collections and various attributes in literature to assist teachers in their efforts to get a handle on their subject matter/data, as well as perform systematic literature reviews. Concisely, so that relevant articles are found, and methodologically accurate are then chosen, which is an important task, and critically assessed to ensure methodological consistency Information is obtained from each time the data are analyzed to ensure the results are reliable, interpretable, and understandable is taken into consideration. Most knowledge was created by referencing secondary literature, which is made up of existing published works or other printed information.

\section{Proposed Model}

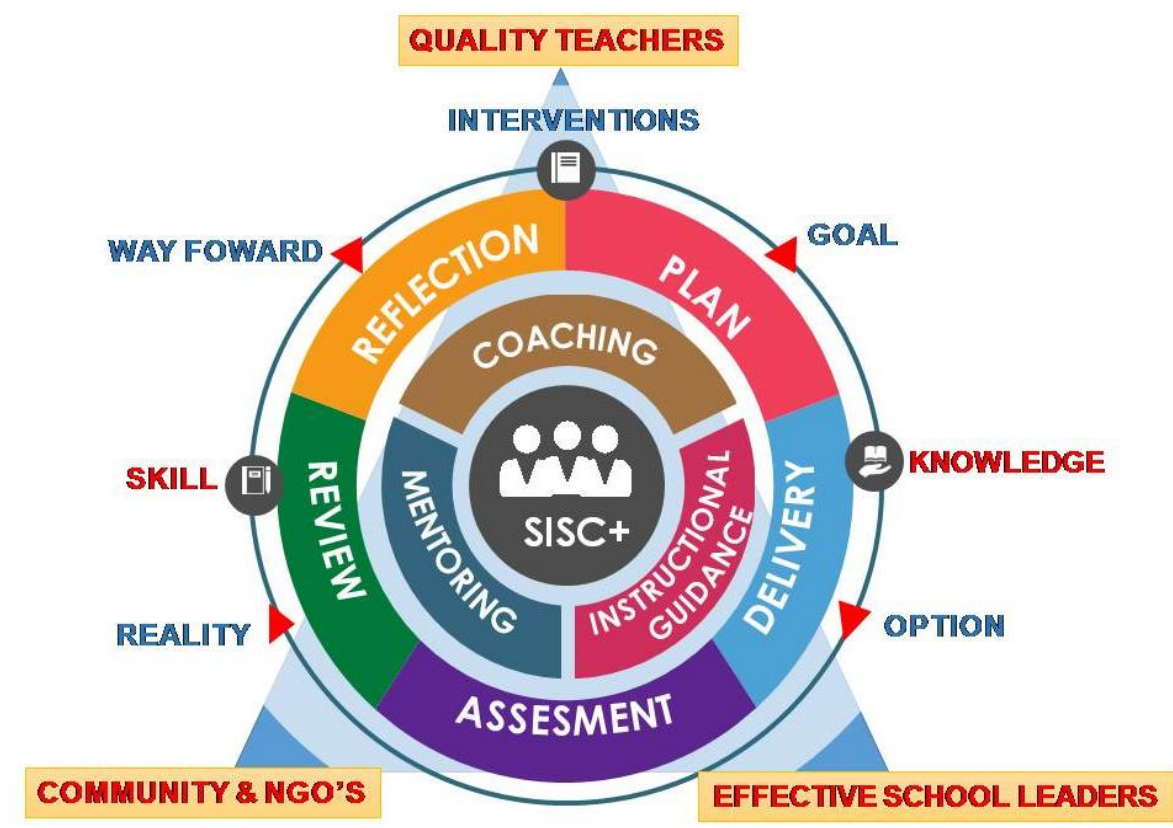

Figure 3.0 Model Of School Improvement Specialist Coaches (SISC+) In Development Teaching Professionalism (Whitmore, 1992)

The researcher developed a model for more in -depth analysis of the concept of SISC+ by adapting the Grow model developed by Whitmore (1992) can be referenced in figure 3.0. In the model produced, the researcher introduced 3 main roles of SISC+ namely guidance, mentoring and instructional guidance. These three roles lead to the implementation of interventions in improving the weaknesses of teachers and enhance the growth of teacher professionalism in terms of knowledge and skills of teachers in improving student development. 5 dimensions in intensive intervention are implemented based on the concept of SISC+ guidance and mentoring in line with the GROW model and the Standard 4 instrument in the Malaysian Education Quality Standard Wave 2 (KPM, 2016 and Norhasma et.al., 2019). The five dimensions of the intervention consist of Plan, Delivery, Assessment, Review and Reflection. 
In the aspect of planning, SISC+ will guide teachers in preparing lesson plan according to a complete format. Lesson planning, teaching and surveys by SISC+. to selected teachers able to address students' problems through 'Lesson Study' able to contribute to improving the skills and competencies of teachers (Amirullah, 2018). SISC+ guides efficient communication approaches in this aspect of delivery. The SISC+ Curriculum Awareness level is highly accountable, qualified and capable of training teachers in schools to produce quality learning and facilitating (Balang et.al., 2020). The authorities must also provide assistance and collaboration to ensure SISC+ provides teachers with quality guidance (Balang et.al., 2020). SISC + officers must keep guiding teachers as qualified teaching personnel to meet their needs to follow the guidelines established and ensure that teachers are guided and student outcomes produced (Khun et.al, 2019).

In the phase of assessment, evaluation will be conducted on the basis of students' performance, comprehension, and participation in the activity. At the review point, all assessments based on student behavior are expected to be discussed, directed, and reviewed with teachers by SISC+ officers. In terms of reflection, the teacher will be guided to write in an appropriate manner under the guidance of SKPMG instruments (KPM, 2016) and the SISC+ officer. The study by Elenchothy and Malathi (2019) also reinforces the positiveness of the standard teacher's pedagogical skills in reflective and reflective writing efforts through SISC+ guidance, despite a minimum improvement of student performance.

In addition, school and school community leaders (parents and teachers), as well as nongovernmental organizations, must provide special assistance for the implementation of coaching initiatives under the guidance of SISC + officers in the development of teacher initiatives. On SISC +, deep and collaborative cooperation between parents and school leaders will improve student excellence and growth, as well as teacher professionalism. Teachers can promote a culture of information sharing from mentors and leadership, as well as diversity, knowledge, and skills sharing among teachers, by working with school leaders [Cheng, 2019]. In a nutshell, SISC+ contributes significantly to the development of teacher professionalism in tandem with the growth of technology and world-class human resources.

\section{Discussion and Implication}

The SISC+ Officer's Role Boosting professional development requires assessing needs through programs performed in collaboration with the teachers they coach. Interventions focused on five aspects, namely Plan, Delivery, Assessment, Review, and Reflection, in accordance with the scope of SISC+ and the Malaysian Education quality standard instrument in wave 2, will help teachers and students develop their weaknesses in order to improve students' abilities and strengths.

SISC+'s instruction interventions, in collaboration with teachers, have the potential to serve as a stepping stone for fundamental change and student excellence. Mentoring interventions by SISC+ on teachers have the potential to develop more data-driven teachers capable of processing challenges and solutions. This intervention's role is not only to enhance student excellence and success, but also to assist teachers in producing scholarly writing such as scholarly articles on teaching methods, action research, and so forth. Additionally, the 
scholarly writing generated by these teachers may be used to demonstrate the development of teacher professionalism.

Additionally, teachers may use data-driven research to help students address obstacles to academic success. Along with scholarly writing, action research, and data-driven research, teachers may present their findings at conferences, seminars, and symposiums, or use them as source material for scholarly sharing through professional learning communities (Mansor et.al., 2020). Thus, it is clear that SISC+ officers' role in guiding and mentoring teachers in schools has the potential to enhance both the professionalism of teaching and the well-being of students.

This model can help middle school leaders to become a center for the development of local school organizational development elements. Thus, the implications of the existence of this model can help middle school leaders build improvement and understanding strategies that aid the development of teacher professionalism and student well -being (Nehez et.al., 2021; Lipscombe et.al., 2021; Li et.al., 2021; and Gunnulfsen et.al., 2021.)

\section{Conclusion}

SISC+ plays an important role in helping and building quality teachers in line with the growth of highly demanding global education from a technical perspective, capable of creating a more developed world society. Thus, teachers are the foundations of world-class human capital growth because they are capable of enhancing students' skills and continuing to improve professional learning through SISC+ initiatives with guidance and mentoring. As a result, policymakers are urged to develop a strategic initiatives to increase the role and credibility of SISC+ officers as a teacher quality program centered on student growth in the future.

\section{Corresponding Author}

Zulhairul Ramlee

SMK Beluran, Peti Surat 30, 90107 Beluran, Sabah, Malaysia.

Email: sirharoldlee@yahoo.com

\section{References}

Al-Bakri, S., \& Troudi, S. (2020). Efl Teachers' Beliefs About Professionalism And Professional Development. Journal of Applied Linguistics And Professional Practice, 15(1), 1-23. Https://Doi.Org/10.1558/Jalpp.34885

Amirullah, A. H. (2018). Lesson Study: An Approach To Increase The Competency Of Out-OfField Mathematics Teacher In Building The Students Conceptual Understanding In Learning Mathematics. Journal of Educational Sciences, 2(2), 1. Doi:10.31258/Jes.2.2.P.1-13

Ansawi, B., \& Pang, V. (2017). The Relationship Between Professional Learning Community And Lesson Study: A Case Study In Low Performing Schools In Sabah, Malaysia. Sains Humanika, 9(1-3). Doi:10.11113/Sh.V9n1-3.1144

Balang, N. J., Mahamod, Z., \& Buang, N. A. (2020). Proficiencies In Curriculum Aspects Among School Improvement Specialist Coaches Plus (Sisc+). Universal Journal Of Educational Research, 8(5a), 89-94. Doi:10.13189/Ujer.2020.081913 
Balang, N. J., Mahamod, Z., \& Buang, N. A. (2020). School Improvement Specialist Coaches Plus (Sisc+) As A Catalyst For Enhancing Teachers Pedagogy Aspect In Malaysia. Open Journal Of Social Sciences, 08(09), 306-314. Doi:10.4236/Jss.2020.89024

Bianco-Mathis, V. E., Nabors, L. K., \& Roman, C. H. (2002). Leading From The Inside Out: A

Bibi, Z., M. A., Hamidah, Y., \& Wahiza, W. (2019). School Improvement Specialist Coaches Plus

(Sisc+) Teacher Coaching In Malaysia: Examining The Studies. International Journal of Contemporary Applied Researches, 6,. Retrieved From Www.ljcar.Net

Chan, C., Chan, V., \& Toong, H. T. (2020). The Impact Of Implementing T.E.A.M Framework Towards Virtual Learning Effectiveness. International Journal Of Creative Multimedia, 1(2), 57-77. Https://Doi.Org/10.33093/ljcm.2020.1.2.4

Cheng, E. C. K. (2019). Knowledge Management Strategiesfor Sustaining Lesson Study. International Journal For Lesson And Learning Studies, 9[2], 167-178. Https://Doi.Org/10.1108/ljlls-10-2019-0070

Coaching Model. California: Sage.

Dembkowski, S., \& Eldridge, F. (2003). Beyond Grow: A New Coaching Model. The International Journal Of Mentoring And Coaching, 1(1), 21.

Gunnulfsen, A. E. (2021). School Leadership And Micro-Policymaking In Schools Time Use And The Collective Care For The Self. International Journal Of Leadership In Education. Https://Doi.Org/10.1080/13603124.2020.1854867

Hatlevik, I. K. R., Engelien, K. L., \&Jorde, D. (2021). The Contribution Of University Schools To The Development Of Teacher Education At The University Of Oslo. Acta Didactica Norge, 14(2). Https://Doi.Org/10.5617/Adno.7913

Huong, W. S., \& Abdullah, N. A. E. B. (2018). Bimbingan Dan Pementoran Pembimbing Pakar Peningkatan Sekolah (Sisc+) Menurut Perspektif Guru Dibimbing (Gdb). International Journal Of Education, Psychology And Counseling, 3(13),57-72. India.

Irmawati, D. K., Asri, T. M., \& Aziz, A. L. (2021). How Efl Teachers Deal With Pedagogical Competence Development For The Teaching Of Writing: A Study On Higher Educational Level In Indonesian Context. Journal Of Education And E-Learning Research, 8(1), 4251. Https://Doi.Org/10.20448/Journal.509.2021.81.42.51

Jimbai, N., Balang, A., \& Mahamod, Z. (2016). Persepsi Dan Proses Bimbingan Sisc+ Terhadap Guru-Guru Bahasa Melayu. Jurnal Penyelidikan Pendidikan Guru, 11, 90-103.

Jusoh, S. (2018). Persepsi, Amalan Dan Keberkesanan bimbingan jurulatih Sisc+ Dari Perspektif Guru Bahasa Melayu [ Perceptions, Practices And Effectiveness Of Sisc + Coach Guidance From The Malay Teacher Perspective] .Jurnal Pendidikan Bahasa Melayu-Jpbm [Journal Of Malay Language Education] 8 (1), 42-52.

Kadir, A., Karuppannan, G., Abdur Rahman, M., \& Kumarasamy, M. M. (2021). The Effects Of Coaching And Mentoring On Metacognition Knowledge Among Malay Language Teachers In Sabah, Malaysia. American International Journal Of Education And Linguistics Research, 18-30. Doi:10.46545/Aijelr.V4i1.284

Kamaruddin, Z., \& Boon, Y. (2020). Challenges In Integrating New Teacher Development Program In Schools: A Systematic Literature Review. Universal Journal Of Educational Research, 8(5a), 81-88. Doi:10.13189/Ujer.2020.08191

Kao, C. P., Wu, Y. T., Chang, Y. Y., Chien, H. M., \& Mou, T. Y. (2020). Understanding Web-Based Professional Development In Education: The Role Of Attitudes And Self-Efficacy In Predicting Teachers' Technology-Teaching Integration. Asia-Pacific Education Researcher, 29(5), 405-415. Https://Doi.Org/10.1007/S40299-019-00493-X 
Keguruan. Kementerian Pendidikan Malaysia: Putrajaya.

Kementerian Pendidikan Malaysia. (2016). Pelan Induk Pembangunan Profesionalisme Leedham, M., \&Parsloe, E. (2017). Coaching And Mentoring: Practical Techniques For Developing Learning And Performance. London: Kogan Page.

Leslie, S., Cimpian, A., Meyer, M., \& Freeland, E. (2015). Expectations Of Brilliance Underlie Gender Distributions Across Academic Disciplines. Science, 347(6219), 262-265. Doi:10.1126/Science.1261375

Li, S. C., Poon, A. Y. K., Lai, T. K. H., \& Tam, S. T. C. (2021). Does Middle Leadership Matter? Evidence From A Study Of System-Wide Reform On English Language Curriculum. International Journal Of Leadership In Education, 24(2), 226-243. Https://Doi.Org/10.1080/13603124.2018.1529823

Lipscombe, K., Tndall-Ford, S., \& Lamanna, J. (2021). School Middle Leadership: A Systematic Review. Educational Management Administration And Leadership. Https://Doi.Org/10.1177/1741143220983328

Madhavan, S., Basri, R., Ayub, M. A. F., \& Asimiran, S. (2020). Kualiti Bimbingan Pengajaran Oleh "Pegawai Pembimbing Pakar Pembangunan Sekolah" (School Improvement Specialist Coaches - Sics+) Sebagai Faktor Peramal Terhadap Kualiti Guru Di Sekolah Kebangsaan. Muallim Journal of Social Science And Humanities, 68-78. Doi:10.33306/Mjssh/82

Mansor A., N., Abdullah, N., \& Abd Rahman, H. (2020). Towards Electronic Learning Features In Education 4.0 Environment: Literature Study. Indonesian Journal Of Electrical Engineering And Computer Science, 19(1), 442. Https://Doi.Org/10.11591/ljeecs.V19.I1. Pp42-450

Mukherjee, S. (2014). Corporate Coaching: The Essential Guide. New Delhi: Sage Publications Muntholib, Hidayat, \& Jaya. (2020). School Head Strategic Management In Developing Education Professionality. International Journal Of Research -Granthaalayah, 7(12), 271-284. Doi:10.29121/Granthaalayah.V7.I12.2019.321

Negotiating The Standard. Bristol: Multilingual Matters.

Nehez, J., Blossing, U., Gyllander Torkildsen, L., Lander, R., \& Olin, A. (2021). Middle Leaders Translating Knowledge About Improvement: Making Change In The School And Preschool Organisation. Journal Of Educational Change.

Https://Doi.Org/10.1007/S10833-021-09418-2

Norhasma W, W. H., \& Yusoff, N. M. (2019). ' Skpmg2' (Standard 4) As Tools To Upgrade Teachers' Teaching Quality. Journal Of Educational Research And Indigeneous Studies, 1(1), 1-11.

Purwasih, R., Anita, I. W., \&Afrilianto, M. (2020). Workshop Dan Pelatihan Pembelajaran Lesson Studi Bagi Guru. Jurnalpengabdian Masyarakat Khatulistiwa, 3(1), 17-24. Https://Doi.Org/10.31932/Jpmk.V3i1.653

Rachmajanti, S., Sulistyo, G. H., Megawati, F., \& Akbar, A. A. N. M. (2020). Professional Development As Viewed By Efl Teachers At Lower Secondary Schools. Jees (Journal Of English Educators Society), 5(2). Https://Doi.Org/10.21070/Jees.V5i2.964

Rimmer, W., \& Floyd, A. (2020). The Contribution Of Conferences To Teachers' Professionalism. In Tesl-Ej (Vol. 24). Editorial Board Tesl - Ej.

Roche, C. (2021). 'Prescription' For Purposeful Adaptation Of Professionalism-And-Ethics Teaching Strategies For Remote Delivery. Pharmacy, 9(1), 55. Https://Doi.Org/10.3390/Pharmacy9010055

Starr, R. L. (2016). Sociolinguistic Variation And Acquisition In Two-Way Language Immersion: 
Theeboom, T., Beersma, B., \& Van Vianen, A. E. (2014). Does Coaching Work? A Meta-Analysis On The Effects Of Coaching On Individual Level Outcomes In An Organizational Context. The Journal Of Positive Psychology, 9(1), 1-18.

Weinstein, N., Brown, K. W., \& Ryan, R. M. (2009). A Multi-Method Examination Of The Effects Of Mindfulness On Stress Attribution, Coping, And Emotional Well-Being. Journal of Research Personality, 43(3), 374-385.

Whitmore, J. (1992). Coaching For Performance: A Practical Guide To Growing Your Own Skills. London: Nicholas Brealey Publishing 